\title{
Glass Formulation Requirements for Hanford Coupled Operations Using Crystalline Silicotitanates (CST)
}

by

M. K. Andrews

Westinghouse Savannah River Company

Savannah River Site

Aiken, South Carolina 29808

J. R. Harbour

DOE Contract No. DE-AC09-96SR18500

This paper was prepared in connection with work done under the above contract number with the U. S. Department of Energy. By acceptance of this paper, the publisher and/or recipient acknowledges the U.S. Government's right to retain a nonexclusive, royalty-free license in and to any copyright covering this paper, along with the right to reproduce and to authorize others to reproduce all or part of the copyrighted paper. 


\section{DISCLAMIXR}

Portions of this document may be illegible in electronic image products. Images are produced from the best available original docoment 


\section{DISCLAIMER}

This report was prepared as an account of work sponsored by an agency of the United States Government. Neither the United States Government nor any agency thereof, nor any of their employees, makes any warranty, express or implied, or assumes any legal liability or responsibility for the accuracy, completeness, or usefulness of any information, apparatus, product, or process disclosed, or represents that its use would not infringe privately owned rights. Reference herein to any specific commercial product, process, or service by trade name, trademark, manufacturer, or otherwise does not necessarily constitute or imply its endorsement, recommendation, or favoring by the United States Government or any agency thereof. The views and opinions of authors expressed herein do not necessarily state or reflect those of the United States Government or any agency thereof.

This report has been reproduced directly from the best available copy.

Available to DOE and DOE contractors from the Office of Scientific and Technical Information, P. O. Box 62, Oak Ridge, TN 37831; prices available from (423) 576-8401.

Available to the public from the National Technical Information Service, U. S. Department of Commerce, 5285 Port Royal Road, Springfield, VA 22161. 
WESTINGHOUSE SAVANNAH RIVER COMPANY

SAVANNAH RIVER TECHNOLOGY CENTER

WSRC-RP-97-0265

\title{
GLASS FORMULATION REQUIREMENTS FOR HANFORD COUPLED OPERATIONS USING CRYSTALLINE SILICOTITANATES (CST) (U)
}

\author{
M. K. Andrews and J. R. Harbour \\ Westinghouse Savannah River Company \\ Aiken, S. C. 29808
}

\section{INTRODUCTION}

The U.S. Department of Energy (DOE) through the Richland Operations Office has requested proposals from the private sector for the treatment of waste from the Hanford Waste Tanks. Phase I of this privatization initiative may include a demonstration for treatment and immobilization of both low activity and high-level waste. If the demonstration includes high-level waste, then the Cs-137 waste stream most likely will be combined with the high-level waste sludge to produce a coupled feed for immobilization (most likely vitrification using a borosilicate glass). It appears that pretreatment will involve the removal of cesium (and perhaps strontium and some transuranic radionuclides) from the supernate using an ion exchange material such as crystalline silicotitanate (CST). The ion exchange sorbent (or the eluted Cs-137) can then be combined with the sludge and vitrified in a coupled operation similar to the DWPF process. Alternatively, the cesium-loaded ion exchange sorbent can be vitrified directly to produce a separate glass waste form.

SRTC has been involved in an Office of Science and Technology (EM-50) funded project to determine if Cs-137 loaded CST can be successfully incorporated into glass at significant levels. ${ }^{1}$ For a waste form which would include only Cs-137 loaded CST, concentrations up to $60 \mathrm{wt} \%$ of CST in glass have been achieved. ${ }^{2}$ The glass produced from this demonstration is both processable and durable. This CST-only waste form could be used at Hanford if the cesium-loaded CST is vitrified in a separate melter. For coupled feed operations, the CST would be mixed with high-level radioactive sludge from the Hanford tanks. This report provides the basis and the path forward for SRTC's efforts at developing a glass frit formulation which will incorporate both Hanford sludge and cesium-loaded CST for a coupled flowsheer. The goal of this work is to demonstrate the feasibility of vitrification as a method for immobilization of coupled feed (specifically, Cs-137-loaded CST). A separate report ${ }^{3}$ has been issued which details the basis and the path forward for the glass formulation efforts for the coupling of DWPF sludge with CST. 


\section{HANFORD TANK WASTE}

Hanford has 177 double and single shell waste tanks which, like the tanks at SRS, contain sludge, salt cake, and supernate. There are a number of types of tank waste at Hanford including Neutralized Current Acid Waste (NCAW), Double Shell Slurry Feed (DSSF), and Single Shell Tanks (SST) waste. The Phase 1 demonstration may immobilize 3 to 6 percent of the High-level waste over a period of 5 to 9 years. ${ }^{4}$

Sludge and Sludge Surrogate. Currently, the High-Level waste demonstration of Phase 1 will treat and immobilize waste from four tanks: 241-AZ-101, 241-AZ-102, 241-AY102, and 241-C-106. ${ }^{4}$ Two of these tanks, 241-AZ-101 and 241-AZ-102, contain 161,000 liters $(267,000 \mathrm{~kg})$ and 333,000 liters $(496,000 \mathrm{~kg})$, respectively, of NCAW waste. Tank 241-AY-102 contains 121,00 liters of sludge $(170,000 \mathrm{~kg})$ and Tank $241-\mathrm{C}$ 106 contains 745,000 liters of sludge $(1,066,000 \mathrm{~kg})$. All of these sludges are slurries diluted by $50 \%$ water.

It has yet to be determined how the waste from these four tanks will be treated. The tanks could be treated separately, blended, or partially blended. The sludge in these tanks most likely will be water-washed but may also be caustic-washed. The caustic wash removes aluminum plus some other non-waste components from the waste.

In order to develop a glass frit formulation for the coupled feed, it is first necessary to define the composition of the sludge which will be used. Lambert, Stegen, and Vienna 4 have provided a nominal blend composition for the four tanks of Phase 1 after both water and caustic washing. This blended average (with caustic wash) has been selected as the sludge composition for this work and is provided in Table 1.

Table 1. Eiemental Composition of Hanford Blended Average

\begin{tabular}{|c|c|}
\hline Element & wt\% \\
\hline $\mathrm{Ag}$ & 0.154 \\
\hline $\mathrm{Al}$ & 5.931 \\
\hline $\mathrm{B}$ & 0.061 \\
\hline $\mathrm{Ba}$ & 0.634 \\
\hline $\mathrm{Ca}$ & 1.726 \\
\hline $\mathrm{Ce}$ & 1.313 \\
\hline $\mathrm{Cl}$ & 0.031 \\
\hline $\mathrm{Co}$ & 0.160 \\
\hline $\mathrm{Cr}$ & 0.268 \\
\hline
\end{tabular}

\begin{tabular}{|c|c|}
\hline Element & wt\% \\
\hline $\mathrm{F}$ & 0.165 \\
\hline $\mathrm{Fe}$ & 20.412 \\
\hline $\mathrm{K}$ & 0.637 \\
\hline $\mathrm{La}$ & 0.519 \\
\hline $\mathrm{Mg}$ & 0.861 \\
\hline $\mathrm{Mn}$ & 0.599 \\
\hline $\mathrm{Na}$ & 16.913 \\
\hline $\mathrm{Nd}$ & 0.404 \\
\hline $\mathrm{Ni}$ & 0.956 \\
\hline
\end{tabular}

\begin{tabular}{|c|c|}
\hline Element & wt\% \\
\hline \hline $\mathrm{P}$ & 0.180 \\
\hline $\mathrm{Pb}$ & 0.371 \\
\hline $\mathrm{Ru}$ & 0.167 \\
\hline $\mathrm{Se}$ & 0.168 \\
\hline $\mathrm{Si}$ & 8.718 \\
\hline $\mathrm{SO} 4$ & 0.843 \\
\hline $\mathrm{Sr}$ & 0.061 \\
\hline $\mathrm{Zr}$ & 3.398 \\
\hline
\end{tabular}

The batch! sheet for the sludge surrogate which was developed from the blended average is shown in Table 2. 
Table 2. Sludge Surrogate Developed from the Blended Average

\begin{tabular}{|c|c|}
\hline Compound & Amount (g) \\
\hline \hline $\mathrm{Al}_{2} \mathrm{O}_{3}$ & 9.102 \\
\hline $\mathrm{AgNO}_{3}$ & 0.197 \\
\hline $\mathrm{Na}_{2} \mathrm{~B}_{4} \mathrm{O}_{7}$ & 0.437 \\
\hline $\mathrm{BaCO}_{3}$ & 0.740 \\
\hline $\mathrm{CaCO}_{3}$ & 3.501 \\
\hline $\mathrm{Ce}\left(\mathrm{NO}_{3}\right)_{3} \cdot 6 \mathrm{H}_{2} \mathrm{O}$ & 3.305 \\
\hline $\mathrm{Co}\left(\mathrm{NO}_{3}\right)_{2} \cdot 6 \mathrm{H}_{2} \mathrm{O}$ & 0.642 \\
\hline $\mathrm{K}_{2} \mathrm{CrO}_{4}$ & 0.813 \\
\hline $\mathrm{Fe}_{2} \mathrm{O}_{3}$ & 23.701 \\
\hline $\mathrm{KNO}_{3}$ & 0.491 \\
\hline $\mathrm{La}_{2} \mathrm{O}_{3}$ & 0.494 \\
\hline $\mathrm{MgO}$ & 1.160 \\
\hline $\mathrm{MnO}_{2}$ & 0.770 \\
\hline
\end{tabular}

\begin{tabular}{|c|c|}
\hline Compound & Amount (g) \\
\hline \hline $\mathrm{Na}_{2} \mathrm{CO}_{3}$ & 31.169 \\
\hline $\mathrm{Nd}_{2} \mathrm{O}_{3}$ & 0.383 \\
\hline $\mathrm{NiCO}_{3}$ & 0.716 \\
\hline $\mathrm{P}_{2} \mathrm{O}_{5}$ & 0.413 \\
\hline $\mathrm{PbO}$ & 0.325 \\
\hline $\mathrm{RuCl}_{3} \cdot 2 \mathrm{H}_{2} \mathrm{O}$ & 0.325 \\
\hline $\mathrm{Se}$ & 0.136 \\
\hline $\mathrm{SiO}_{2}$ & 15.147 \\
\hline $\mathrm{Sr}_{\left(\mathrm{NO}_{3}\right)_{2}}$ & 0.120 \\
\hline $\mathrm{ZrO}_{2}$ & 3.728 \\
\hline $\mathrm{NaF}$ & 0.296 \\
\hline $\mathrm{NiSO}_{4} \cdot 6 \mathrm{H}_{2} \mathrm{O}$ & 1.892 \\
\hline
\end{tabular}

Supernate. The NCAW, DSSF, and SST supernates have different chemical compositions and amounts of Cs-137. The NCAW supernate contains relatively high amounts of Cs-137 whereas the DSSF and SST tanks contain significantly less Cs-137. The sodium, potassium, and Cs-137 concentrations in Hanford NCAW, DSSF, and SST waste ${ }^{5}$ are provided in Table 3, along with information from SRS and Oak Ridge MVST tanks for comparison.

Table 3. Cs-137, Na, and K Concentrations in Hanford NCAW, DSSF, and SST Waste, SRS and ORNL MVST Wastes

\begin{tabular}{|c||c|c|c|c|c|}
\hline & $\begin{array}{c}\text { Cs-137 } \\
(\mathbf{m g} / \mathbf{L})\end{array}$ & $\begin{array}{c}\text { Cs-137 } \\
\text { Curies }\end{array}$ & $\begin{array}{c}\text { Na } \\
\text { (molar) }\end{array}$ & $\begin{array}{c}\text { K } \\
\text { (molar) }\end{array}$ & $\begin{array}{c}\text { VOLUME } \\
\text { (liters) }\end{array}$ \\
\hline \hline SRS & 20 & $2.5 \mathrm{E}+08$ & 14 & 0.1 & $1.1 \mathrm{E}+08$ \% \\
\hline $\begin{array}{c}\text { Hanford } \\
\text { NCAW }\end{array}$ & 25 & $1.3 \mathrm{E}+07$ & 5 & 0.1 & $6.7 \mathrm{E}+06$ \\
\hline Hanford DSSF & 4 & $1.3 \mathrm{E}+07$ & 8.5 & 0.8 & $4.9 \mathrm{E}+07$ \\
\hline Hanford SST & 0.5 & $1.8 \mathrm{E}+07$ & 5 & $* *$ & $4.5 \mathrm{E}+08$ \\
\hline ORNL MVST & 0.15 & $1.4 \mathrm{E}+04$ & 4.1 & 0.4 & $7.5 \mathrm{E}+05$ \\
\hline
\end{tabular}

* Includes supernate and saltcake ** Data not available

An alternate approach to characterizing the Hanford supernate is to define a blend of all waste supernate (including dissolved saltcake). This has been done by Kurath et $\mathrm{al}^{6}$ and their report provides data on this average supernate obtained by blending the supernate from all the tanks at Hanford and normalizing to $5 \mathrm{M}$ sodium. According to this report, there will be 674 million liters of supernate with $47 \mathrm{Ci} / \mathrm{m}^{3}$ of Cs-137. This translates to a total of 32 million $\mathrm{Ci}$ of $\mathrm{Cs}-137$ in the supernate. The blended supernate contains a potassium concentration of $0.027 \mathrm{M}$ and a sodium concentration of $5 \mathrm{M}$. There are 2.8 $\mathrm{Ci} / \mathrm{m}^{3}$ of $\mathrm{Sr}-90$. 


\section{AMOUNT OF CST REQUIRED}

Calculations have been performed by M. E. Johnson of TWRS Systems Engineering to determine the amount of CST required to treat the supernate in Hanford NCAW, DSSF, and SST tanks. A summary of the calculations is provided in Table 4 . These calculations assumed a multiple batch, counter-current process and a requirement to reduce the final cesium concentration to less than the Class A limit of $1 \mathrm{Ci} / \mathrm{m}^{3}$. Since the limit for the final cesium concentration has not been established, the calculations in Table 4 could change significantly. For instance, the Class C limit of $4600 \mathrm{Ci} / \mathrm{m}^{3}$ would dramatically reduce the amount of CST required. However, restricting the final cesium concentration to 0.1 of the Class A limit, would significantly increase the amount of CST necessary. ${ }^{5}$

Table 4. Amount of supernate present in Hanford Tanks and the estimated amount of CST required to treat this supernate (from Michael E. Johnson, TWRS Systems Engineering)

\begin{tabular}{|c|c|c|c|c|c|c|}
\hline & $\begin{array}{l}\text { Volume } \\
\text { liters } \\
\end{array}$ & $\begin{array}{c}\text { Cs-137 } \\
\mathrm{Ci} \\
\end{array}$ & $\begin{array}{c}\text { Cs-137 } \\
\text { kg } \\
\end{array}$ & $\begin{array}{c}\text { CST Req'd } \\
\mathrm{kg} \\
\end{array}$ & $\begin{array}{c}\text { Cs-137 } \\
\text { Loading } \\
\text { Ci/g CST } \\
\end{array}$ & $\begin{array}{c}\text { Cs-137 } \\
\text { Loading } \\
\text { wt } \%\end{array}$ \\
\hline NCAW & $6.70 \mathrm{E}+06$ & $1.26 \mathrm{E}+07$ & 145 & $5.00 \mathrm{E}+04$ & 0.252 & 0.29 \\
\hline DSSF & $4.90 \mathrm{E}+07$ & $1.29 \mathrm{E}+07$ & 148 & $4.50 \mathrm{E}+05$ & 0.029 & 0.033 \\
\hline SST & $4.50 \mathrm{E}+08$ & $1.75 \mathrm{E}+07$ & 201 & $1.24 \mathrm{E}+06$ & 0.014 & 0.016 \\
\hline
\end{tabular}

The total amount of CST required to treat the supernates in the NCAW, DSSF, and SST is $1.74 \times 10^{6} \mathrm{~kg}$. However, the amount of CST required depends significantly on the composition, in addition to the amount, of supernate.

Using SRS simulated salt solutions, McCabe showed that the Cs-137 loading on CST is dependent upon the cesium, sodium and potassium concentrations in the supernate. ${ }^{7}$ For fixed sodium and potassium levels, McCabe demonstrated a range of 1.2 to $4.6 \mathrm{wt} \%$ cesium sorption on powdered CST depending upon the cesium concentration in solution. For the cesium in the DWPF supernate, which contains 38 atom\% Cs-137, these values correspond to 0.5 to $1.8 \mathrm{wt} \%$ Cs-137 sorption on the CST. Comparison of these values to the Cs-137 loadings listed in Table 4 shows that only the NCAW approaches the DWPF range.

One explanation for the difference in Cs-137 loadings between the Hanford and DWPF supernates is the difference in composition. It has been shown that higher concentrations of potassium lead to less cesium sorption. ${ }^{8}$ At $5 \mathrm{M}$ sodium, the Hanford blended supernate is $0.027 \mathrm{M}$ potassium, and the SRS simulant supernate is $0.015 \mathrm{M}$ potassium. In addition, the cesium concentration in the average Hanford supernate is only $3 \mathrm{mg} / \mathrm{L}$, compared to the lowest tested values of $28 \mathrm{mg} / \mathrm{L}$ for the SRS supernate. Extrapolation of McCabe's data to the Hanford level of cesium, indicates $\sim 0.02 \mathrm{wt} \%$ sorption of Cs-137, which is close to the values for the DSSF and SST supernates $(0.033$ and $0.016 \cdot \mathrm{wt} \%$ respectively). 
For the NCAW supernate, the cesium concentration is $25 \mathrm{mg} / \mathrm{L} \mathrm{Cs}-137$, which is only slightly less than that tested by McCabe $(28 \mathrm{mg} / \mathrm{L})$. However, the NCAW supernate has a higher potassium level $(0.1 \mathrm{M})$ than the tested DWPF simulant which contained $0.015 \mathrm{M}$ potassium. This would explain the lower Cs-137 capacity calculated for the NCAW waste $(0.29 \mathrm{wt} \%$ compared to $0.5 \mathrm{wt} \%$ for DWPF).

Although there is uncertainty in calculating the amount of CST that will be required to treat all of the Hanford supernate, the values in Table 4 represent good estimates based on the results of McCabe on DWPF simulated supernate.

\section{CST LOADING IN THE GLASS}

The total amount of glass which will be produced to treat all of the Hanford sludge has been estimated at $2.28 \times 10^{7} \mathrm{~kg}$ for a $45 \mathrm{wt} \%$ waste oxide loading. The total amount of CST required to treat all of the Hanford Tank supernates is $1.74 \times 10^{6} \mathrm{~kg}$. Therefore, a balanced CST/sludge feed would require, with no increase in the amount of glass or canisters produced, a $7.6 \mathrm{wt} \%$ loading of CST in glass.

The goal is to develop a glass frit formulation which will incorporate $\sim 45 \mathrm{wt} \%$ sludge waste oxides and $\sim 7.6 \mathrm{wt} \%$ Cs-137 loaded CST. This would maintain the glass production at $\sim 2.28 \times 10^{7} \mathrm{~kg}$ of glass.

\section{PATH FORWARD}

A sludge surrogate has been developed based on a blended average of the four tanks which will be used during Phase 1 of the privatization process. For the entire tank waste treatment, a coupled feed (with balanced sludge and CST) containing $7.6 \mathrm{wt} \%$ CST has been estimated. For this work, the uncertainties around these estimates will be taken into account by attempting to develop a frit formulation(s) which can incorporate between 5 and $15 \mathrm{wt} \%$ CST while maintaining as high a level as possible of the sludge surrogate (roughly $45 \mathrm{wt} \%$ oxide loading).

\section{REFERENCES}

1. D. M. Ferrara, Immobilization of IX Resins (CST), WSRC Immobilization, TTP SR16WT31, Waste Tanks Immobilization, Task Number B, October, 1996.

2. M. K. Andrews and J. R. Harbour, Effect of CST Ion Exchange Loading on the Volume of Glass Produced During the Vitrification Demonstration at SRTC (U), WSRC-TR-96-0372, Rev. 0, November, 1996.

3. M. K. Andrews and J. R. Harbour, Glass Formulation Requirements for DWPF Coupled Operations Using Crystalline Silicotitanates (U), WSRC-TR-970004, January, 1997.

4. S. L. Lambert, G. E. Stegen, and J. D. Vienna, Tank Waste Remediation System Phase 1 High-Level Waste Feed Processability Assessment Report, WHC-SDWM-TI-768, Rev. 0, August, 1996.

5. R. S. Goheen and D. E. Kurath, Conceptual Study of In-Tank Cesium Removal Using an Inorganic Ion Exchange Material, PNNL-11114, March, 1994. 
6. D. E. Kurath, K. P. Brooks, G. W. Hollenberg, R. Clemmer, S. Balagopal, T. Landro, and D. P. Sutija, Preconceptual Design of a Salt Splitting Process Using Ceramic Membranes, PNNL-11454, UC-2030, January, 1997.

7. D. J. McCabe, Crystalline Silicotitanate Examination Results (U), WSRC-RP94-1123, May, 1995.

8. R. Braun, T. J. Dangieri, D. J. Fennelly, J. D. Sherman, W. C. Schwerin, R. R. Willis, et al, Crystalline Silicotitanates-Novel Commercial Cesium Ion Exchangers, Spectrum ‘96, Seattle, Washington, August 1996.

\section{DISTRIBUTION}

M. K. Andrews, 773-A

N. E. Bibler, 773-A

D. A. Crowley, 773-43A

E. F. Duhn, 773-A

T. L. Fellinger, 773-A

D. M. Ferrara, 773-43A

J. R. Harbour, 773-43A

E. W. Holtzscheiter, 773-A

L. F. Landon, 704-1T

D. J. McCabe, 773-43A

L. M. Papouchado, 773-A

C. T. Randall, 704-T 